\title{
SENYAWA BIOAKTIF MIKROALGA DAN PROSPEKNYA DI MASA DEPAN
}

\author{
Oleh \\ Indyaswan Tegar Suryaningtyas ${ }^{1)}$
}

\begin{abstract}
BIOACTIVE COMPOUND FROM MICROALGAE AND ITS FUTURE

PROSPECT. Microalgae biomass is potential to be used in various fields, one of which is as a producer of bioactive compounds. Bioactive compounds from microalgae can be used extensively in the pharmaceutical industry, cosmetic's raw materials, food flavouring substances, and functional food ingredients. In terms of health, the bioactive compounds have the potential as antioxidants, antiviral, antibacterial, anti-fungal, anti-inflammatory, anti-tumor, and prevent the effects of malaria, but the potential for microalgae's bioactive compound has not been explored well if compared to the production of terrestrial plants. Some examples of the bioactive compounds that have been used are carotenoid groups such as lutein, $\beta$-carotene, astaxanthin and fucoxanthin; fatty acid groups such as EPA and DHA; and also some toxin compounds such as domoic acid. To obtain the optimum yield of bioactive compounds, it requires the right method in biomass production, compound extraction, compounds isolation and compounds identification. While testing the activities, it is necessary to do some assays such as antioxidan, antibiotic, antiviral and anticancer assay. The development of the technology can improve the potential use of microalgae to synthesis its bioactive compounds.
\end{abstract}

\section{PENDAHULUAN}

Mikroalga telah dimanfaatkan sebagai bahan baku biomassa yang potensial dalam berbagai macam bidang mulai dari bidang kesehatan, kosmetika, industri budidaya, dan bahkan untuk bahan bakar alternatif pengganti bahan bakar fosil (Chen et al., 2011). Sebagai organisme ber sel tunggal, mikroalga dapat menggunakan nutrisi dengan lebih efisien untuk melakukan metabolisme, pertumbuhan atau menghasilkan senyawa kimia. Salah satu yang menjadi perhatian adalah senyawa bioaktif alami yang dihasilkan yang dapat dimanfaatkan di dalam industri farmasi, bahan baku kosmetika, dan zat penambah rasa makanan serta bahan pangan fungsional. Kandungan mikroalga seperti asam lemak, protein, klorofil, karotenoid, dan beberapa vitamin sangat menarik untuk dikembangkan dalam skala komersial (Raposo et al., 2013). Manfaat dari produk senyawa bioaktif mikroalga memiliki peluang untuk menjadi solusi dari berbagai isu kesehatan sebagai antioksidan, antivirus, antibakteri,

\footnotetext{
$\overline{{ }^{1)} \text { Laboratorium Mikroalga, Pusat Penelitian Oseanografi LIPI }}$
} 
antijamur, antiradang, antitumor, dan mencegah efek dari malaria ( $\mathrm{Hu}$ et al., 2008).

Potensi-potensi produk senyawa yang berasal dari mikroalga masih belum banyak dipelajari dan dimanfaatkan bila dibandingkan dengan produk senyawa yang dihasilkan oleh tumbuhan darat, meskipun sebenarnya mikroalga memiliki beberapa kelebihan dibandingkan tumbuhan darat. Kelebihan tersebut diantaranya adalah produksi biomassa yang lebih tinggi hingga 30 kali lebih cepat dibandingkan tumbuhan darat, lebih mudah dikultur dan dipanen, serta tidak mengurangi lahan pertanian (Richmon et al., 2013). Keunggulan-keunggulan ini mendukung pentingnya pengembangan mikroalga sebagai penghasil produk alami yang potensial dalam industri kesehatan dan farmasi. Dari ribuan jenis mikroalga di dunia, hanya sebagian kecil yang sudah dipelajari lebih jauh dan dideskripsikan secara ilmiah (Jijakli et al., 2015). Menurut Richmon et al. (2015), keragaman komponen senyawa bioaktif yang dihasilkan oleh mikroalga diperkirakan 10 kali lebih beragam daripada produk senyawa yang dihasilkan oleh tumbuhan darat. Termasuk di dalamnya adalah metabolit sekunder maupun metabolit basal yang spesifik terhadap kondisi lingkungan tertentu. Berdasarkan fakta tersebut, bisa dikatakan bahwa produk senyawa bioaktif dari mikroalga memiliki potensi besar yang belum banyak terungkap.

\section{MIKROALGA DAN PRODUK ALAMINYA}

Mikroalga adalah salah satu organisme yang memiliki jenis paling bervariasi dan tersebar luas mulai dari air tawar hingga di air laut (Gimpel et al., 2015). Mikroalga merupakan organisme prokariotik seperti cyanobakteria, alga hijau, diatom dan beberapa kelompok organisme eukariotik. Salah satu kelompok besar mikroalga adalah alga hijau yang termasuk dalam Filum Chlorophyta dengan karakteristik utama memiliki pigmen hijau, klorofil, seperti Chlorella, Dunaliella, dan Nannochloropsis. Kelompok yang lain adalah diatom, yang terdiri dari Filum Heterokontophyta dengan anggota yang berasal dari Genus Phaeodactylum (Boyd et al., 1997). Beberapa spesies mikroalga yang sudah umum digunakan sebagai produk terapi kesehatan untuk menyembuhkan penyakit maupun sebagai suplemen kesehatan antara lain adalah spirulina Arthrospira platensis yang merupakan salah satu jenis dari sianobakteri, dan alga hijau Chlorella pyrenoidosa.

Alga hijau telah lama dimanfaatkan sebagai pewarna alami. Namun tidak banyak diketahui bahwa pigmen yang terkandung di dalam alga hijau bukan hanya klorofil saja (Hong et al., 2015). Sebagai contoh, Haematococcus mengandung pigmen yang bervariasi, salah satunya adalah astaxanthin (Kim et al., 2016). Astaxanthin banyak digunakan sebagai bahan suplemen kesehatan karena memiliki kapasitas sebagai antioksidan serta memiliki fungsi kesehatan yang lain. 
Selain Genus Haematococcus sebagai genus yang telah banyak dipelajari sebagai penghasil Astaxanthin, beberapa spesies Chlorella juga memproduksi senyawa tersebut. Meskipun demikian, Chlorella dan Haematococcus menggunakan jalur metabolisme yang berbeda dalam sintesis senyawa tersebut (Hong et al., 2015). Sedangkan Dunaliella salina sudah sejak lama dimanfaatkan untuk memproduksi $\beta$-karoten. Ekstrak dari D. salina memberikan sitotoksisitas yang signifikan terhadap sel neuroblastoma, namun tidak berefek kepada sel normal yang sehat (Anila et al., 2016). Fukosantin yang dihasilkan diatom mampu menghambat efek sel kanker dengan memengaruhi aktivitas proapoptosisnya. Selain itu, fucoxanthin juga menunjukkan aktivitas antioksidan, antiperadangan, antiobesitas, antidiabetes, dan antimalaria yang cukup efektif ketika diuji di dalam penelitian (Yi et al., 2015; Peng et al., 2011).

Selain pigmen, mikroalga secara umum memproduksi asam lemak rantai panjang tak jenuh ganda atau biasa disebut polyunsaturated long-chain fatty acids (PUFAs) yang memiliki banyak manfaat untuk kesehatan (Chitranjali et al., 2015). Selama ini, PUFAs diproduksi dariminyak ikan. Namun setelah adanya pencemaran logam berat dan isu eksploitasi ikan yang berlebihan, alternatif sumber PUFAs pun semakin banyak dicari, dan pilihan yang tepat jatuh pada mikroalga. Beberapa mikroalga menjadi kandidat potensial sebagai sumber PUFAs di dalam produk suplemen kesehatan, antara lain, Crypthecodinium, Nannochloropsis, Phaeodactylum, Monodus, Nitzchia, dan Isocrysis (Munanda et al., 2011).

\section{PEMANFAATAN SENYAWA BIOAKTIF MIKROALGA}

Mikroalga menghasilkan produk yang telah banyak dimanfaatkan dalam dunia kesehatan. Beberapa contoh kelompok senyawa bioaktif yang berasal dari mikroalga yang sudah umum dimanfaatkan antara lain adalah karotenoid, asam lemak esensial dan polisakarida (Tabel 1). $\beta$-karoten adalah salah satu karotenoid primer yang merupakan bagian dari organ fotosintesis, sedangkan astaxanthin adalah contoh dari karotenoid sekunder yang hanya akan terakumulasi ketika terjadi stimulus tertentu (Guedes et al., 2011). D. Salina adalah mikroalga dengan kandungan $\beta$-karoten yang tertinggi (hingga 10\% dari berat kering biomasa), disusul oleh Isochrysis sp. di urutan kedua (Prieto et al., 2011). Astaxanthin telah diproduksi secara komersial dari ekstraksi alga hijau Haematococcus sp., sedangkan fukosantin dari ekstraksi diatom Phaeodactylum tricornutum sebanyak $16,5 \mathrm{mg} / \mathrm{g}$ berat keringnya (Xia et al., 2013). 
Tabel 1. Karotenoid dan asam lemak esensial yang berasal dari mikroalga (Fu et al., 2017).

\begin{tabular}{|c|c|c|}
\hline Senyawa & Spesies mikroalga & $\%$ berat kering \\
\hline \multicolumn{3}{|l|}{ Karotenoid } \\
\hline Lutein & Dunaliella salina & $0,4 \%-0,8 \%$ \\
\hline$\beta$-karoten & Dunaliella salina & $10 \%$ \\
\hline Fucoxanthin & $\begin{array}{l}\text { Chaetoceros sp., Cylindrotheca sp., } \\
\text { Odontella sp., Phaeodactylum sp., } \\
\text { Isochrysis sp. }\end{array}$ & $1,5 \%-2,0 \%$ \\
\hline Astaxanthin & $\begin{array}{l}\text { Haematococcus sp., } \\
\text { H. pluvialis }\end{array}$ & $1 \%-8 \%$ \\
\hline \multicolumn{3}{|c|}{ Asam lemak esensial } \\
\hline $\begin{array}{l}\text { Eicosapentaen } \\
\text { oic acid (EPA) }\end{array}$ & $\begin{array}{l}\text { Phaeodactylum tricornutum, } \\
\text { Monodus subterraneus, } \\
\text { Porphyridium cruentum, Amphora sp. }\end{array}$ & $0.7 \%-6.1 \%$ lipid total \\
\hline $\begin{array}{l}\text { Docosahexaenoic } \\
\text { acid (DHA }\end{array}$ & $\begin{array}{l}\text { Spirulina platensis, } \\
\text { Rhizosolenia setigera, } \\
\text { Thalassiosira stellaris, } \\
\text { Crypthecodinium cohnii, Isocrysis sp. }\end{array}$ & $17.5 \%-30.2 \%$ lipid total \\
\hline
\end{tabular}

Selain karotenoid dan senyawa bioaktif yang lain, mikroalga juga berpotensi sebagai sumber asam lemak esensial, seperti eicosapentaenoic acid (EPA) dan docosahexaenoic acid (DHA). Pada diatom, produksi EPA dan DHA secara berurutan bisa mencapai hingga $17,5 \%-30,2 \%$ dan $0,7 \%-6,1 \%$ dari total asam lemak yang dihasilkan. Sedangkan asam lemak total yang dihasilkan diatom dapat mencapai $57,8 \%$ dari berat kering selnya (Xia et al., 2013). Diatom juga diketahui sebagai penghasil senyawa toksik, seperti domoic acid (DA) yang pada tahun 1987 menyebabkan kematian masal dan komplikasi kesehatan pada manusia yang mengkonsumsi kerang budidaya yang diberi pakan diatom Pseudonitzschia (Prieto et al., 2011). Senyawa toksik dapat dimanfaatkan untuk kesehatan apabila digunakan dalam jumlah yang sesuai. DA dalam dosis kecil dimanfaatkan secara medis di Jepang untuk membasmi cacing di dalam usus besar (Berge et al., 1997). Penelitian Barofsky (2007) menunjukkan bahwa DA yang berasal dari ekstrak diatom Skeletonema costatum memiliki aktivitas antiproliferasi terhadap sel kanker paru.

\section{EKSTRAKSI DAN PENGUJIAN SENYAWA BIOAKTIF}

Mikroalga yang dimanfaatkan untuk produksi senyawa penting adalah strain hasil isolasi dari alam. Isolat tersebut dikembangkan dengan kultur hingga mencapai skala industri lalu kemudian diekstrak senyawa yang diinginkan. Beberapa permasalahan timbul dalam 
proses isolasi maupun proses kultur yaitu kurangnya informasi mengenai kebutuhan nutrisi untuk tumbuh seperti fosfor, sulfur dan sumber nitrogen; serta pH optimal, suhu, intensitas cahaya dan kepadatan optimal untuk tumbuh. Setiap strain mikroalga memiliki karakteristik parameter tersendiri untuk mendapatkan kondisi optimalnya ( $\mathrm{Fu}$ et al., 2014). Penelitian mengenai optimasi pertumbuhan mikroalga dan produksi senyawa bioaktifnya mencakup proses isolasi yang efisien menjadi kultur unialgal aksial, ekstraksi dan isolasi yang efektif untuk senyawa bioaktif dan analisis strukturalnya, dan penentuan bahan kimia dari senyawa bioaktif yang potensial.

Pada proses ekstraksi senyawa bioaktif, semakin tinggi efisiensi proses ekstraksi, hasil ekstrak senyawa pun akan semakin tinggi dan bervariasi. Metode ekstraksi yang sering dilakukan saat ini masih sangat tergantung dengan pemilihan pelarut, dan memerlukan pelarut organik dalam jumlah besar dan menghabiskan banyak waktu. Untuk mengatasi permasalahan tersebut, banyak dikembangkan teknik ekstraksi yang lebih efisien, dengan metode otomatis, hanya memerlukan pelarut organik yang lebih sedikit, ramah lingkungan, dan lebih efisien dalam pengerjaannya. Beberapa contoh teknik ekstraksi yang saat ini sedang dikembangkan dan telah menunjukkan hasil yang lebih baik antara lain supercritical fluid extraction (SFE), pressurized fluid extraction (PFE), ultrasound-assisted extraction, dan microwave-assisted extraction
(Hernandez-Ledesma \& Herrero, 2014). Metode SFE menggunakan supercritical fluid (SCF) untuk meningkatkan efisiensinya. SCF adalah zat/bahan yang dipanaskan atau diberi tekanan melebihi titik kritisnya (critical points). Saat ini, SCF yang paling banyak digunakan untuk tujuan analisis dan ekstraksi adalah karbon dioksida $\left(\mathrm{SC}-\mathrm{CO}_{2}\right)$, terutama untuk ekstraksi senyawa - senyawa antioksidan dan lipid. Sedangkan metode PFE membuat agar pelarut berada pada suhu dan tekanan yang tinggi untuk mempertahankannya dalam keadaan cair. Suhu yang digunakan berkisar antara $100^{\circ}$ hingga $200^{\circ} \mathrm{C}$ (Hernandez-Ledesma \& Herrero, 2014).

Proses penapisan atau screening produk alami senyawa bioaktif dilakukan dengan dua pendekatan, yaitu isolasi terlebih dahulu atau pengujian terlebih dahulu. Masing-masing pendekatan berhasil menunjukkan potensi produk bioaktif alami, dan saat ini kombinasi antara dua pendekatan tersebut sedang dikembangkan dimana ekstraksi total atau fraksi ekstrak diuji kemudian langsung dilanjutkan dengan bioassay apabila ditemukan aktivitas biologi yang tinggi (Xia et al., 2013). Sebagai contoh, liquid chromatography-mass spectrometry (LC-MS) dan/atau nuclear magnetic resonance (NMR) dapat digunakan untuk menggambarkan profil karakterisasi kimia dari ekstrak total maupun bagian dari ekstrak, ketika ditemukan senyawa baru, senyawa tersebut dipurifikasi dan dianalisis dengan pengujian biologis (biological assays). Kombinasi dua pendekatan tersebut diharapkan dapat 
lebih cepat, murah, sensitif, mudah dilakukan, dan dapat diulang kembali (Xia et al., 2013).

Ekstrak mikroalga seperti karotenoid dan senyawa bioaktif lainnya memiliki potensi sebagai antioksidan. Efektivitas ekstrak mikroalga sebagai antioksidan diuji dengan beberapa metode yang saat ini dikembangkan, salah satu contoh adalah metode ferricreducing ability of the plasma atau biasa disebut dengan FRAP yang banyak digunakan untuk mendeteksi antioksidan pada diatom (Fu et al., 2017). Sedangkan untuk uji antibiotik, metode yang paling sering digunakan adalah uji difusi untuk melihat efektivitas aktivitas antibiotik terhadap bakteri gram positif, gram negatif dan jamur dengan parameter luasan bidang yang tidak ditumbuhi bakteri (Xia et al., 2013). Pengujian antivirus mikroalga dilakukan dengan bermacam metode seperti lempeng mikro (microplate). Senyawa hasil ekstraksi mikroalga ditemukan terdapat aktivitas perlawanan terhadap beberapa jenis retrovirus seperti virus herpes, togavirus, rhabdovirus dan bahkan HIV (Fu et al., 2017). Salah satu senyawa hasil isolasi dari ekstrak mikroalga adalah Cyanovirin-N, senyawa polipeptida yang diekstrak dari Nostoc ellipsosporum, yang menunjukkan hasil yang kuat dalam melawan virus HIV-1 (Boyd et al., 1997). Sebagai tambahan, steroid dan glikolipid, serta polisakarida sulfat yang diekstrak dari mikroalga juga menunjukkan aktivitas antivirus (Fu et al., 2017). Ekstrak mikroalga juga menunjukkan aktivitas antikanker, dengan pengukuran menggunakan layar toksisitas sel (toxicity screen) dengan menggunakan sel-sel kanker yang diberi pewarna vital (seperti MTT 3-(4,5-dimethylthiazol2-yl)-2,5-diphenyltetrazolium bromide dan sulforhodamine B (Fu et al., 2017). Sebagai contoh, dolastatin 10, senyawa dari ekstrak cyanobakteri Symploca sp. memiliki potensi sitotoksik kepada sel kanker. Strukturdarisenyawainikemudian menjadi model produksi senyawa sintesis auristatin PE yang berikatan dengan antibody dan melawan sel kanker (Xia et al., 2013). Sedangkan senyawa lain yang juga berpotensi sebagai antikanker seperti iejimalide A yang merupakan penghambat produksi V-ATPase; curacin A yang memiliki efek antimitosis; dan debromoplysiatoxin dan lyngbyatoxin yang merupakan aktivator protein kinase $\mathrm{C}$ belum memiliki ijin pemakaian dari Food and Drug Administration (FDA, Amerika) (Hernandez-Ledesma \& Herrero, 2014). Aktivitas antikanker pada ekstrak mikroalga ini belum sepenuhnya dapat dimanfaatkan sebagai obat kanker, namun saat ini menjadi alternatif untuk mengurangi efek buruk kanker selama obat kanker masih dalam tahap pengembangan.

\section{BIOSINTESIS SENYAWA BIOAKTIF}

Produk alam dari mikroalga termasuk senyawa dengan struktur yang kompleks dan bervariasi merupakan hasil adaptasi mikroalga terhadap lingkungan fisik habitatnya. Misalnya produksi pigmen untuk memanfaatkan cahaya dan melindungi diri dari paparan sinar matahari; produksi terpenoid, isofrenil 
dan beberapa molekul untuk dapat bersaing dengan spesies lain; produksi gula dan polimer-polimer yang berperan dalam kondisi cekaman suhu dan osmosis, serta sebagai cadangan energi (Gimpel et al., 2015). Kondisi morfologi dan fisiologi mikroalga mengharuskan mikroalga untuk beradaptasi lebih banyak daripada tanaman darat yang cenderung lebih mudah beradaptasi, sehingga biosintesis senyawa yang merupakan hasil adaptasi tersebut juga lebih bervariasi dibandingkan dengan produk dari tanaman darat (Richmond et al., 2013).

Pemahaman tentang biosintesis senyawa bioaktif mikroalga diperlukan untuk usaha optimasi senyawa yang diinginkan. Sebagai contoh, jalur metabolisme biosintesis lipid mikroalga telah berhasil dipetakan dengan pendekatan molekuler. Hal ini mempermudah proses peningkatan produksi PUFA dengan memanfaatkan gen-gen yang telah diketahui berperan dalam jalur metabolismenya. Gen-gen tersebut direkayasa agar ekspresinya meningkat, sehingga biosintesis PUFA pun meningkat (Chitranjali et al., 2015). Jalur metabolisme lain yang telah berhasil dipetakan adalah jalur biosintesis $\beta$-karoten (Anila et al., 2016). Anila et al. (2016) melakukan analisis perbandingan proses biosintesis $\beta$-karoten pada beberapa spesies alga hijau dan mengambil kesimpulan bahwa jalur biosintesis $\beta$-karoten bervariasi di tiap spesies. Hal tersebut menyebabkan perlunya penanganan khusus yang spesifik dalam pemberian perlakuan untuk meningkatkan produksi $\beta$-karoten pada tiap spesies yang berbeda.

\section{PROSPEK DI MASA DEPAN}

\section{Pemanfaatan senyawa} biokatif dari mikroalga masih terus dikembangkan, berbagai metode optimasi produksi biomassa, metode ekstraksi, metode isolasi dan identifikasi senyawa bioaktif, dan metode sintesis senyawa terus mengalami perkembangan yang semakin baik. Ditambah dengan minat masyarakat yang semakin besar terhadap suplemen yang berasal dari bahan alami, dapat diperbarui dan mudah diproduksi, ramah lingkungan, maka prospek mikroalga sebagai bahan pangan fungsional menjadi semakin tinggi (Chen et al., 2011). Dalam industri farmasi dan pangan fungsional, ketersediaan bahan baku menjadi kunci keberlanjutan usaha. Sulitnya pemenuhan bahan baku akan menjadi penghambat tersendiri dalam suatu industri. Sebagai contoh, saat ini PUFA diperoleh terutama dari ekstrak minyak ikan. Semakin meningkatnya kebutuhan PUFA tidak sebanding dengan tingkat penangkapan ikan yang ketersediaannya semakin menurun dan diperburuk lagi dengan banyaknya peraturan pembatasan penangkapan ikan. Kondisi seperti ini menjadi penyebab ketidakpastian masa depan industri PUFA yang berasal dari ekstrak minyak ikan, dan mikroalga adalah salah satu alternatif solusi dari permasalahan tersebut $(\mathrm{Fu}$ et al., 2017). Bahan baku biomasa mikroalga lebih mudah diproduksi secara masal, pertumbuhan yang cepat karena efesiensi dalam penggunaan nutrisi dan 
kemampuannya dalam berfotosintesis mendukung kemudahan untuk produksi biomasa ini (Gimpel et al., 2015). Karena mikroalga dikembangkan dalam air, maka kondisi dan desain tempat kultur dapat disesuaikan dengan ketersediaan lahan. Selain itu, dengan kondisi alam Indonesia dengan garis pantai yang panjang dan mudahnya sumber air laut, pemilihan lokasi tidak menjadi masalah yang sulit.

Perkembangan bioteknologi dewasa ini turut mendukung pemanfaatan mikroalga sebagai penghasil senyawa bioaktif. Sebagian besar senyawa bioaktif yang dihasilkan oleh mikroalga adalah metabolit sekunder, yang secara seluler produksinya rendah. Sehingga produksi masal dan ekstraksi tunggal untuk senyawa bioaktif dari kultur mikroalga (tanpa modifikasi dan rekayasa) dirasa masih kurang ekonomis. Disisi lain, sintesis senyawa bioaktif dengan bahan kimia buatan juga memerlukan biaya yang besar untuk biaya produksinya. Belum lagi permasalahan proses pembuatan senyawa yang cukup rumit karena struktur senyawa yang kompleks membuat senyawa buatan tidak sebagus produk alaminya (Fu et al., 2017). Namun dengan adanya kemajuan bioteknologi, "pabrik" biomasa mikroalga dapat dibuat menjadi lebih optimal. Penggunaan ilmu dan metode mutagenesis, evolusi adaptif, rekayasa genetika, dan sintesis biologi merupakan solusi yang terus dikembangkan. Kemajuan pengetahuan secara molekuler seperti keberhasilan sekuensing genom komplit dari beberapa spesies mikroalga, berkembanganya software dan tools untuk genomeediting, metabolisme model dengan skala genomik, dan perkembangan omics data (transkriptomik, metagenomik, proteinomik, metabolomik dan sebagainya) dapat menyediakan informasi untuk optimasi produksi biomasa maupun meningkatkan produksi senyawa metabolit yang diinginkan dalam suatu kultivasi (Hernandez-Ledesma \& Herrero, 2014).

Biomasa mikroalga selain menghasilkan senyawa bioaktif, juga menghasilkan produk yang lain seperti lipid yang berpotensi menjadi sumber bahan bakar alternatif di masa depan pengganti bahan bakar fosil. Mikroalga juga dapat dimanfaatkan sebagai bahan pangan fungsional seperti menjadi sumber protein, serat, dan vitamin yang baik untuk kesehatan manusia atau sebagai pakan biota budidaya. Hasil ekstraksi mikroalga dapat juga digunakan sebagai bahan biomaterial untuk pembuatan silika. Produksi biomasa mikroalga akan menjadi lebih efisien apabila dalam sekali produksi biomasa, berbagai produk dapat dihasilkan. Hal ini didukung oleh penelitian mengenai biorefinary mikroalga supaya tidak ada sisa ekstraksi yang terbuang percuma (Raposo et al., 2013). 


\section{PENUTUP}

Mikroalga memiliki potensi sebagai bahan baku senyawa bioaktif yang saat ini dibutuhkan sebagai solusi kesehatan. Senyawa-senyawa bioaktif seperti astaxanthin, fucoxanthin, EPA, DHA, adalah contoh dari beberapa senyawa yang diproduksi oleh mikroalga yang potensial secara ekonomi dan secara kesehatan. Senyawa yang diproduksi mikroalga masih banyak yang belum terungkap, yang mungkin memiliki dampak yang besar bagi dunia kesehatan. Sangat besar kemungkinan perkembangan penemuan senyawa - senyawa tersebut, begitu pula dengan potensi pasar yang besar. Informasi mengenai karakter senyawa, manfaat senyawa, dan potensinya perlu untuk diteliti dan diketahui agar pemanfaatannya bisa lebih optimal. Pengujian efektivitas dan aktivitas senyawa metabolit seperti pengujian antimikrobia, antivirus, antikanker, efek imunologi, juga perlu dilakukan, bersamaan dengan dikembangkannya metode ekstraksi, metode isolasi senyawa dan preservasinya. Sebagai kesimpulan, walaupun masih terus dikembangkannya usaha optimasi produksinya, senyawa bioaktif yang dihasilkan mikroalga memiliki potensi yang besar sebagai solusi bermacam masalah kesehatan di masa depan.

\section{DAFTAR PUSTAKA}

Anila, N. D. P. Simon, A. Chandrashekar, G. A. Ravishankar and R. Sarada. 2016. Metabolic engineering of Dunaliella salina for production of ketocarotenoids, Photosynth. Res. 127 : 321-333.

Barofsky, A. and G. Pohnert. 2007. Biosynthesis of polyunsaturated short chain aldehydes in the diatom Thalassiosira rotula. Org. Lett. 9 (6) : 1017-1020.

Berge, J. P., N. Bourgougnon, D. Carbonnelle, V. Le Bert, C. Tomasoni, P. Durand and C. Roussakis. 1997. Antiproliferative effects of an organic extract from the marine diatom Skeletonema costatum (Grev) Cleve against a nonsmall-cell bronchopulmonary carcinoma line (NSCLC-N6), Anticancer Research.17 (3c) : 2115-2120.

Boyd, M. R., K. R. Gustafson, J. B. McMahon, R. H. Shoemaker, B. R. O'Keefe, T. Mori, R. J. Gulakowski, L. Wu, M. I. Rivera, C. M. Laurencot, M. J. Currens, J. H. Cardellina, R. W. Buckheit, Jr, P. L. Nara, L. K. Pannell, R. C. Sowder and L. E. Henderson. 1997. Discovery of cyanovirin-N, a novel human immunodeficiency virus inactivating protein that binds viral surface envelope glycoprotein gp120: potential 
applications to microbicide development, Antimicrobial Agents and Chemotherapy. 41 (7) : 1521-1530.

Chen, C.Y., K.L. Yeh, R. Aisyah, R, D.J. Lee and J.S. Chang. 2011. Cultivation, photobioreactor design and harvesting of microalgae for biodiesel production: A critical review. Bioresource Technology, 102 : 71-81.

Chitranjali, T., P. Chandran and G. Kurup, 2015. Omega-3 fatty acid concentrate from Dunaliella salina possesses anti-inflammatory properties including blockade of NFkappaB nuclear translocation, I $\mathrm{m} \mathrm{m} \mathrm{u} \mathrm{nop} \mathrm{h} \mathrm{a} \mathrm{r} \mathrm{m} \mathrm{a} \mathrm{c} \mathrm{o} 1$. Immunotoxicol. 37 (1) : 81-89.

Fu, W.Q., G. Paglia, M. Magnúsdóttir, E. A. Steinarsdóttir, S. Gudmundsson, B. Ø. Palsson, Ó. S. Andrésson and S. Brynjólfsson. 2014. Effects of abiotic stressors on lutein production in the green microalga Dunaliella salina, Microbial Cell Factories 13. 3.

Fu, W. D.R. Nelson, Z.Yi., M. Xu, B. Khraiwesh, K. Jijakli, A. Chaiboonchoe, A. Alzahmi, D. Al-Khairy, S. Brynjolfsson and K. Salehi-Ashtiani. 2017. Bioactive Compounds from Microalgae: Current Development and Prospects. Studies in Natural Products Chemistry. 54 : 199-225.
Gimpel, J.A., J.S. Hyun, N. G. Schoepp and S. P. Mayfield. 2015. Production of recombinant proteins in microalgae at pilot greenhousescale.Biotechnology and Bioenginering. 112 (2) : 339-345.

Guedes, A.C., H.M. Amaro and F.X. Malcata. 2011. Microalgae as sources of carotenoids.Marine Drugs 9 (4) : 625-644.

Hernandez-Ledesma, B.and M. Herrero. 2014. Bioactive Compounds from Marine Foods: Plant and Animal Sources, in: IFT Press, Wiley Blackwell, Chichester. Xix. 437p.

Hong, M.E., S. K. Hwang, W. S. Chang, B. W. Kim, J. Lee and S.J. Sim. 2015. Enhanced autotrophic astaxanthin production from Haematococcus pluvialis under high temperature via heat stressdriven Haber-Weiss reaction. Appl. Microbiol. Biotechnol. 99 (12) : 5203-5215.

Hu, Q., M. Sommerfeld, E. Jarvis, M. Ghirardi, M. Posewitz, M. Seibert and A. Darzins. 2008. Microalgal triacylglycerols as feedstocks for biofuel production: perspectives and advances. Plant J. 54 (4) : $621-$ 639.

Jijakli, K., R. Abdrabu, B. Khraiwesh, D. R. Nelson, J. Koussa and K. Salehi-Ashtiani. 2015. Molecular genetic techniques 
for algal bioengineering. Biomass and Biofuels from Microalgae.Springer International Publishing, Basel, Switzerland. pp. 155171.

Kim, D.Y., D. Vijayan, R. Praveenkumar, J.I. Han, K. Lee, J. Y. Park, W.S. Chang, J. S. Lee and Y. K. Oh. 2016. Cell-wall disruption and lipid/astaxanthin extraction from microalgae: Chlorella and Haematococcus.Bioresour. Technol. 199 : 300-310.

Mutanda, T., D. Ramesh, S. Karthikeyan, S. Kumari, A. Anandraj and F. Bux. 2011. Bioprospecting for hyper-lipid producing microalgal strains for sustainable biofuel production. Bioresour. Technol. 102 (1) : 57-70.

Peng, J., J. P. Yuan, C. F. Wu and J. H. Wang. 2011. Fucoxanthin, a marine carotenoid present in brown seaweeds and diatoms: metabolism and bioactivities relevant to human health, Mar. Drugs 9 (10) : 1806-1828.

Prieto, A., J.P. Canavate and M. GarciaGonzalez. 2011. Assessment of carotenoid production by Dunaliella salina in different culture systems and operation regimes. J. Biotechnol. 151 (2) : 180-185.
Raposo, M.F.D., R.M.S.C. de Morais and A.M.M.B. de Morais. 2013. Health applications of bioactive compounds from marine microalgae. Life Sci. 93 (15) : 479-486.

Richmond, A. and Q. Hu. 2013. Handbook of Microalgal Culture: Applied Phycology and Biotechnology, second ed., John Wiley \& Sons, Ltd, Chichester.xvi, 719 pages.

Xia, S.K. Wang, L. Wan, A. Li, Q. $\mathrm{Hu}$ and C. Zhang. 2013. Production, characterization, and antioxidant activity of fucoxanthin from the marine diatom Odontella aurita. Mar. Drugs 11 (7) : 2667-2681.

Yi, Z.Q., M. Xu, M. Magnusdottir, Y. Zhang, S. Brynjolfsson and W. Fu. 2015. Photo-oxidative stress-driven mutagenesis and adaptive evolution on the marine diatom Phaeodactylum tricornutum for enhanced carotenoid accumulation, Mar. Drugs 13 (10). 6138-6151. 